\title{
Renesans czy zmierzch idei uniwersytetów trzeciego wieku? Refleksje i wnioski z realizacji projektu „UTW: Uczyć - Tworzyć - Wspierać”
}

The renaissance or twilight of the idea of the University of the Third Age? reflections and conclusions from the project "U3A - Learning - Creating - Supporting"

Streszczenie. Artykuł prezentuje założenia, przebieg, refleksje i wnioski z projektu pt. „UTW: Uczyć - Tworzyć - Wspierać” finansowanego przez MNiSW, w ramach programu „Wsparcie Uniwersytetów Trzeciego Wieku”. W artykule obok zarysu historii UTW, podejmowane są próby udzielenia odpowiedzi na następujące pytania: Jaka jest przyszłość uniwersytetów trzeciego wieku w Polsce? Czy w drugiej dekadzie XXI wieku obserwujemy ich zmierzch? A może wręcz przeciwnie - jesteśmy świadkami renesansu tej placówki edukacyjnej? Autorki bazując na wstępnej analizie założonych celów projektu „UTW” oraz działań podejmowanych na rzecz osób starszych, wskazują kilka kierunków rozwoju, w których, ich zdaniem, mogą zmierzać i zmierzają uniwersytety trzeciego wieku.

Słowa kluczowe: uniwersytet trzeciego wieku, współpraca, wolontariat, projekt, osoby starsze

Summary. The article presents the assumptions, process, reflections and conclusions from the project entitled “U3A - Learning - Creating - Supporting” (UTW: Uczyć - Tworzyć Wspierać") funded by the Ministry of Science and Higher Education, as part of the "Support for Universities of the Third Age" program. The authors, beside description of the project and outline of the U3A's development, face up some questions: What is the future of the U3A in Poland? Are we watching their twilight in the second decade of the 21st century? or maybe on the contrary - we are witnessing the renaissance of this educational institution? And referring to theory and practice they try to give the answers. Based on a preliminary analysis of the objectives of the project and activities undertaken for the benefit of older people, the 
authors point to several directions of development in which, in their opinion, U3A follow or can follow.

Key words: University of the Third Age (U3A), cooperation, volunteering, project, older adults

\section{Początki rozwoju UTW}

Jaka jest przyszłość uniwersytetów trzeciego wieku (UTW) w Polsce? Czy w drugiej dekadzie XXI wieku obserwujemy ich zmierzch? A może wręcz przeciwnie - jesteśmy świadkami renesansu tej placówki edukacyjnej? Zanim udzielimy odpowiedzi na tak zadane pytania, warto wrócić do początków powstania idei uniwersytetów trzeciego wieku.

UTW definiowany jest jako przestrzeń aktywizacji i uczenia się osób starszych lub, jak twierdzi Adam A. Zych (2010, s. 195), ośrodek kształcenia typu uniwersytetu otwartego, przeznaczony przede wszystkim dla osób starszych. Pierwszy uniwersytet trzeciego wieku powstał w roku 1973 przy Wydziale Nauk Społecznych Uniwersytetu w Tuluzie, we Francji, za sprawą Pierre'a Vellasa (1924-2005), profesora prawa międzynarodowego. Od tego momentu upłynęło ponad 40 lat, które zaowocowały powstaniem wielu uniwersytetów trzeciego wieku na całym świecie (m. in.: w Polsce, Czechach, Wielkiej Brytanii, Niemczech, Włoszech, Szwecji, Argentynie, Brazylii, Chinach, Kanadzie). UTW z oczywistych względów różnią się od siebie. Jednak tym, co je łączy, jest wizja poprawy jakości życia osób starszych, zarówno poprzez tworzenie przestrzeni spotkania, jak i szeroko rozumianego rozwoju. Uniwersytety trzeciego wieku, jako placówki kształcenia ustawicznego, oferują seniorkom i seniorom wykłady, warsztaty, lektoraty, seminaria, konwersatoria, koła zainteresowań, grupy, a także różnego rodzaju sekcje tj. muzyczna, medyczna, fotograficzna, turystyczna (http://utw.uni.wroc. pl/zajecia/sekcje-kluby). Są zatem, jak podkreśla Adam Zych (2010, s. 195), rodzajem wspólnoty edukacyjnej organizowanej przez osoby, które chcą być aktywne na emeryturze, i dla takich osób. Ich zadaniem jest realizowanie takich celów jak: „podtrzymywanie na duchu, dawanie wartościowego i szlachetnego zajęcia oraz poprawa warunków życia [...], przez aktywizację psychiczną intelektualną i fizyczną, włączanie osób starszych do systemu edukacji permanentnej, nauczanie «sztuki życia» w trzecim wieku przez wdrażanie profilaktyki gerontologicznej, a także prowadzenie gerontologicznych badań naukowych" (Zych 2010, s. 195). 
Uniwersytety trzeciego wieku są obecnie, jak twierdzi Beata Ziębińska (2010, s. 163), „międzynarodowym ruchem zachęcającym osoby starsze do kontynuowania nauki przez całe życie i umożliwiającym spędzanie czasu w grupie rówieśniczej”. Cele pierwszego UTW obejmowały dodatkowo: umożliwienie osobom starszym podjęcie kształcenia ustawicznego, edukowanie studentów w zakresie gerontologii społecznej, przygotowanie odpowiedniej kadry specjalistów pracujących na rzecz ludzi starszych, prowadzenie badań dotyczących szeroko rozumianej problematyki starzenia się i starości (Ziębińska 2010, s. 166). Zaproponowana przez Vellasa idea aktywizacji osób starszych dała początek ruchowi uniwersytetów trzeciego wieku. Popularność UTW we Francji, a w dalszej konsekwencji w Europie sprawiła, że współcześnie są one uznawane za jedne z wiodących placówek realizujących misję aktywizacji osób starszych, zarówno w Polsce, jak i na świecie.

W Polsce pierwszy UTW powołany został w roku 1975 przy Centrum Medycznym Kształcenia Podyplomowego w Warszawie. Jego założycielką była profesor Halina Szwarc (1923-2002). Jako doktor nauk medycznych i gerontolożka, Szwarc współpracowała z Vellasem, w rezultacie czego w stolicy utworzono pierwszy uniwersytet trzeciego wieku pod nazwą Studium III Wieku. Była to jedna z pierwszych placówek tego typu w Europie (po Francji i Belgii). Rok później, w 1976 r., powołany został pierwszy UTW we Wrocławiu, w historii którego można wyróżnić trzy okresy: lata 1976-1979 powołanie Studium Trzeciego Wieku, którego organizatorem i opiekunem naukowym został Czesław Kempisty (lekarz), a kierownikiem Karol Węgier; lata 1979-1997 - Studium Trzeciego Wieku uzyskało status Uniwersytetu Trzeciego Wieku z siedzibą w Medycznym Studium Zawodowym, Kierowniczką UTW została mgr Alina Woźnicka; lata 1997-2018 - w 1997 siedziba Uniwersytetu Trzeciego Wieku przeniesiona została do pomieszczeń Instytutu Pedagogiki Uniwersytetu Wrocławskiego (UWr) i zaczęła funkcjonować pod patronatem Rektora UWr., w roku 1999 decyzją Kolegium Rektorskiego Uniwersytetu Wrocławskiego UTW umieszczono w strukturach UWr. jako jednostkę ogólnouczelnianą. Funkcję Kierownika UTW od roku 1997 pełnili / pełniły w kolejności: dr Walentyna Wnuk (1997-2006); dr Aleksander Kobylarek (2006--2016); dr Małgorzata Malec-Rawiński (2016-2017). Od roku 2017 Kierowniczką UTW w UWr jest dr Bogna Bartosz (http://utw.uni. wroc.pl/utw/historia).

Na przełomie XX i XXI wieku liczba UTW w Europie zaczęła gwałtownie wzrastać. Wśród czynników, które wpłynęły na zaistniałą sytuację wymienić można między innymi: stały wzrost liczby osób starszych w ogólnej 
liczbie ludności, a co za tym idzie potrzebę podejmowania działań zmierzających do aktywizacji tej subpopulacji. Zaobserwowano wzmożony rozwój zainteresowania tematyką starzenia się i starości, a także ideą uczenia się przez całe życie (ang. Lifelong Learning Programme, LLP). Pojawiły się działania wspierające UTW, zarówno w kontekście finansowym, jak merytorycznym (m. in. przez Polsko-Amerykańską Fundację Wolności (PAFW). Powstała Ogólnopolska Federacja Stowarzyszeń Uniwersytetów Trzeciego Wieku (2007), Federacja Uniwersytetów Trzeciego Wieku z siedzibą we Wrocławiu (2014). Rezultatem dokonujących się wówczas zmian był intensywny wzrost liczby UTW w Polsce. Obecnie szacuje się, że jest ich $614^{* *}$.

Wśród zadań stawianych współczesnym uniwersytetom trzeciego wieku wymienić można, za Olgą Czerniawską (2009, s. 98), między innymi optymalizację warunków życia i tworzenie możliwości wszechstronnego rozwoju seniorów / seniorek. W XXI wieku UTW jest miejscem spotkań, wymiany doświadczeń i wiedzy, przestrzenią szeroko rozumianej aktywizacji osób starszych. Oznacza to, że nie może on być palcówką o charakterze „zamkniętym". Instytucją edukacyjną izolującą się od innych placówek, organizacji, społeczności, generacji - m.in. poprzez unikanie działań międzypokoleniowych. Taka wizja UTW - UTW „skierowanego do środka” - w dłuższej perspektywie może sprzyjać marginalizacji i tworzeniu swoiście rozumianych przestrzeni wykluczenia seniorów / seniorek, potocznie określanych "gettami”.

Wraz ze wzrostem liczby osób starszych w ogólnej liczbie ludności rośnie zainteresowanie UTW. Jaka jest zatem przyszłość uniwersytetów trzeciego wieku w Polsce? Naszym zdaniem odpowiedź na to pytanie wymaga głębszego namysłu. UTW jako placówka kształcenia ustawicznego przyczynia się do zaspokajania m. in. takich potrzeb seniorów / seniorek, jak: samokształcenie, poszerzanie wiedzy i umiejętności, a także utrzymywanie kontaktów towarzyskich. Warto się zastanowić, czy i w jakim stopniu realizowane są inicjatywy sprzyjające pogłębianiu dialogu międzypokoleniowego, a także czy podejmowane są działania mające na celu wzmacnianie solidarności oraz współpracy międzygeneracyjnej, które jawią się nam jako jeden z ważniej-

* Dla przykładu, „w końcu 2014 r. liczba ludności Polski wynosiła 38,5 mln, w tym ponad 8,5 mln stanowiły osoby w wieku 60 lat i więcej (ponad 22\%). W latach 1989-2014 liczba osób w starszym wieku wzrosła o ponad 2,9 mln, w tym największy wzrost - o $1 \mathrm{mln}$ odnotowano dla grupy 60-64 latków. Udział osób w wieku co najmniej 60 lat w ogólnej populacji wzrósł o 7,5 punktu procentowego, tj. z 14,7\% w 1989 r. do 22,2\% w 2014 r. Dla porównania odsetek dzieci i młodzieży zmniejszył się w tym czasie o ponad 12 p.proc. z prawie 30\% do 18\%" (GUS, http://www.stat.gov.pl)

** Źródło danych: Baza UTW, stan na dzień 31.03.2017 r., opracowanie: Ogólnopolska Federacja Stowarzyszeń Uniwersytetów Trzeciego Wieku. 
szych postulatów dalszego, pomyślnego funkcjonowania UTW. Świadomość dokonujących się zmian społeczno-kulturowych rodzi konieczność poszukiwania nowych, innowacyjnych kierunków rozwoju UTW, a także potrzebę szerszego otwierania się tych placówek na społeczność lokalną, organizacje pozarządowe, firmy i instytucje. Jedną z możliwych dróg rozwoju nowej wizji UTW, wizji odpowiadającej potrzebom i oczekiwaniom seniorów / seniorek XXI wieku, jest inicjowanie i partycypowanie w projektach, zarówno tych międzynarodowych, jak i krajowych, które będą: przyczyniały się do rozwoju intelektualnego i aktywizacji osób starszych; wspomagały działania międzygeneracyjne, integracyjne, edukacyjne i animacyjne; przeciwdziałały marginalizacji seniorów / seniorek - szczególnie tych z małych społeczności lokalnych (Malec 2011).

\section{Projekt „UTW: Uczyć - Tworzyć - Wspierać” i jego założenia}

Na podstawie komunikatu Ministra Nauki i Szkolnictwa Wyższego (MNiSW) z dnia 12 października 2016 r. o ustanowieniu programu pod nazwą „Wsparcie Uniwersytetów Trzeciego Wieku" (M.P. poz. 980) ogłoszony został konkurs na finansowanie projektów, których celem będzie upowszechnianie nauki oraz badań naukowych i ich zastosowań wśród słuchaczy uniwersytetów trzeciego wieku”. Konkurs, jak wyjaśnia MNiSW, „został ogłoszony po raz pierwszy w ramach tzw. Strategii Gowina, której jednym z filarów jest społeczna odpowiedzialność nauki. Celem programu jest wsparcie istniejących UTW lub umożliwienie założenia zupełnie nowych ośrodków" (http://www. nauka.gov.pl/aktualnosci-ministerstwo/4-mln-zl-dla-uniwersytetow-trzeciego-wieku.html). W niniejszym konkursie wyłoniono 16 najlepszych projektów, a łączna kwota dofinansowania wyniosła blisko $4 \mathrm{mln}$ zł.

Wśród projektów, które otrzymały dofinansowanie był projekt „UTW: Uczyć - Tworzyć - Wspierać” („UTW”), opracowany i złożony przez zespół koordynowany przez dr Małgorzatę Malec-Rawiński (Kierowniczkę UTW w UWr. w 2016 r.). Warto dodać, że niniejszy projekt otrzymał dofinansowanie jako jedyny na Dolnym Śląsku. W realizacji projektu "UTW" udział brały: Uniwersytet Trzeciego Wieku w Uniwersytecie Wrocławskim, który był liderem i beneficjentem projektu, oraz sześć lokalnych uniwersytetów trzeciego wieku z Dolnego Śląska: Międzykulturowa Akademia Trzeciego Wieku przy Ewangelikalnej Wyższej Szkole Teologicznej (Wrocław), Stowarzyszenie Uniwersytet Trzeciego Wieku w Strzelinie, Stowarzyszenie Transgraniczny Uniwersytet Trzeciego Wieku z siedzibą w Zgorzelcu, Uniwersytet Trzeciego 
Wieku w Głuszycy, Oławski Uniwersytet Trzeciego Wieku, Legnicki Uniwersytet Trzeciego Wieku przy Centrum Kształcenia Zawodowego i Ustawicznego oraz nowopowstały Gryfowski Uniwersytet Trzeciego Wieku.

Partnerzy projektu, lokalne uniwersytety trzeciego wieku, reprezentują trzy typy funkcjonujących w Polsce UTW. Pierwszy z nich stanowią placówki działające w strukturach (pod patronatem) uczelni wyższych lub instytucji edukacyjnych (model francuski), kierowane najczęściej przez Pełnomocnika Rektora danej uczelni i tworzone na mocy uchwały senatu. Takimi uniwersytetami w projekcie były: UTW w UWr, Międzykulturowa Akademia Trzeciego Wieku prowadzona przez Ewangelikalną Wyższą Szkołę Teologiczną we Wrocławiu, Legnicki Uniwersytet Trzeciego Wieku przy Centrum Kształcenia Zawodowego i Ustawicznego (CKZiU). Drugi typ stanowią UTW niezależne od uczelni, prowadzone m.in. przez organizacje pozarządowe (model brytyjski). Takimi UTW w projekcie były: Stowarzyszenie Transgraniczny Uniwersytet Trzeciego Wieku w Zgorzelcu, Stowarzyszenie Strzeliński Uniwersytet Trzeciego Wieku, Stowarzyszenie Uniwersytet Trzeciego Wieku w Głuszycy. Trzeci typ to UTW powoływane przy Ośrodkach Kultury i Centrach (model brytyjski), takimi UTW w projekcie były: Oławski Uniwersytet Trzeciego Wieku działający w oparciu o Statut Centrum Sztuki w Oławie oraz powołany w trakcie projektu „UTW” Uniwersytet Trzeciego Wieku w Gryfowie Śląskim, który powstał przy Miejsko-Gminnym Ośrodku Kultury w Gryfowie Śląskim.

Wstępne dane na temat potrzeb i oczekiwań lokalnych UTW zebrane zostały na podstawie wywiadów telefonicznych, prowadzonych przed rozpoczęciem realizacji projektu. W trakcie rozmów zgłaszano przede wszystkim: potrzebę wzbogacenia oferty dydaktycznej placówek, chęć nawiązania współpracy z edukatorami / edukatorkami, wykładowcami / wykładowczyniami, animatorami / animatorkami spoza społeczności lokalnej, zainteresowanie poznaniem funkcjonowania innych UTW oraz gotowość do dzielenia się wiedzą i doświadczeniami. Głównym założeniem projektu było stworzenie platformy wymiany doświadczeń, wiedzy i dobrych praktyk pomiędzy partnerskimi UTW na Dolnym Śląsku. Funkcję koordynacyjną w projekcie pełnił zespół z UTW w UWr - najstarszego uniwersytetu trzeciego wieku na Dolnym Śląsku. Skład zespołu projektowego stanowiły badaczki / naukowczynie, osoby zatrudnione w instytucjach senioralnych, wykładowczynie, 
edukatorki, nauczycielki, animatorki współpracujące z UTW w UWr*, a także superwizorzy / superwizorki (słuchacze / słuchaczki UTW w UWr ${ }^{* *}$ ).

Projekt „UTW: Uczyć - Tworzyć - Wspierać” ukierunkowany był przede wszystkim na potrzeby seniorów / seniorek z niewielkich, lokalnych UTW na Dolnym Śląsku, mających ograniczone zasoby lokalowe i kadrowe. Ponieważ placówki edukacyjne tego typu często mierzą się z problemami związanymi z utrudnionym dostępem do wykwalifikowanej kadry naukowo-dydaktycznej: profesorów / profesorek, doktorów / doktorek, edukatorów / / edukatorek, animatorów / animatorek (posiadających odpowiednie kwalifikacje i kompetencje do prowadzenia zajęć dla osób starszych), zespół projektowy zdecydował się w taki sposób zaplanować działania, by w rezultacie stworzyć sieć partnerskich UTW, które będą się wzajemne wspierały, wymieniały wiedzą, dobrymi praktykami i zasobami kadrowymi, w trakcie realizacji i po zakończeniu projektu.

\section{Cele projektu „UTW” i ich realizacja}

Wokół triady „Uczyć - Tworzyć - Wspierać” zbudowana została koncepcja działań zmierzających do odkrycia i wzmocnienia potencjału lokalnych UTW poprzez działania: edukacyjne, animacyjne i konsultacyjne. Intencją pomysłodawczyń projektu było połączenie wiedzy naukowej z zakresu gerontologii z praktyką edukacyjną i doświadczeniami partnerów. Z tego powodu zaplanowano zarówno wątki badawcze (badanie potrzeb edukacyjnych słuchaczy / słuchaczek UTW - ankieta), jak i praktyczne: wykłady, warsztaty, konsultacje, działania animacyjne skierowane do słuchaczy / słuchaczek UTW, edukatorów / edukatorek, liderów / liderek. Celem głównym projektu było promowanie idei całożyciowego uczenia się w oparciu o: lokalne zasoby UTW, współpracę ze społecznością lokalną, wielowymiarowe wsparcie merytoryczne ze strony lidera, wymianę doświadczeń, wzajemne inspirowanie się, odkrywanie potencjałów lokalnych UTW, a także stymulowanie do

* Koordynatorką projektu „UTW” była dr Małgorzata Malec-Rawiński, jej zastępczynią i menadżerką modułu II - mgr Ilona Zakowicz, menadżerką modułu I - mgr Anna Gużda, menadżerkami modułu III - dr Aleksandra Marcinkiewicz-Wilk i dr Monika Humeniuk oraz specjalistką ds. rozliczeń - mgr Magdalena Wites-Czerwińska.

** Skład Zespołu ds. Superwizji w projekcie „UTW”: Stanisława Warmuz (przewodnicząca), Krystyna Błońska, Renata Babac-Stencel, Halina Cebula, Łucha Dydyna, Teresa Dźwigałowska, Beata Chłap, Grażyna Kubik, Maria Kucharska, Maria Marchwicka, Mieczysław Dąbrowski, Stefania Gorgoń, Teodozja Oleszkiewicz-Grzebieluch, Teresa Hyżak, Teresa Tomków, Bronisława Strzelecka, Jerzy Sosnowski,Wanda Paszke, Andrzej Wołoszyn. 
podejmowania nowych inicjatyw i poszukiwania innowacyjnych rozwiązań w zakresie realizacji działań edukacyjnych, animacyjnych i konsultacyjnych.

Wśród założonych w projekcie zadań szczegółowych wymienić należy między innymi: budowanie sieci wsparcia między uniwersytetami trzeciego wieku, kształtowanie i promowanie pozytywnego wizerunku osób starszych oraz pomyślnych relacji międzygeneracyjnych, upowszechnianie idei wolontariatu wśród słuchaczek i słuchaczy uniwersytetów trzeciego wieku, prezentowanie amatorskich grup artystycznych, inicjowanie i wspieranie działań o charakterze międzygeneracyjnym, przeciwdziałanie społecznemu wykluczeniu seniorów / seniorek poprzez podtrzymywanie więzi społecznych i dialog międzypokoleniowy.

Projekt „UTW” podzielony został na trzy moduły: I - Wymiana dobrych praktyk; II - Działania edukacyjne; III - Upowszechnianie nauki, które realizowane były przez okres sześciu miesięcy (luty-maj / październik-listopad, 2017 r.). Pierwszy moduł ukierunkowany został na wymianę dobrych praktyk i spotkań w lokalnych UTW. W drugim module, odbyły się wykłady, warsztaty i konsultacje - zarówno dla seniorów / seniorek, jak i edukatorów / edukatorek osób starszych. Na szczególną uwagę zasługuje moduł trzeci. Jego głównym celem było włączenie osób starszych do uczącej się wspólnoty akademickiej poprzez uczestnictwo słuchaczy / słuchaczek partnerskich uniwersytetów w zajęciach akademickich - mieszczących się w stałej ofercie dydaktycznej jednostek Wydziału Nauk Historycznych i Pedagogicznych UWr. (WNHiP, UWr.). Inspiracją dla tego modułu był skandynawski model edukacji dorosłych*, który koordynatorka projektu dr M. Malec-Rawiński poznała i zaimplementowała w projekcie "UTW”.

MODUŁ I - wymiana dobrych praktyk. Celem tego modułu było wzajemne poznanie się partnerów projektu i inspirowanie, budowanie partnerskich relacji, promowanie idei współpracy i atmosfery życzliwości, wymiana wiedzy, doświadczeń i dobrych praktyk. Partnerzy projektu połączeni w diady odwiedzali się wzajemnie, prezentując ofertę edukacyjną i artystyczną swojego UTW. W ramach I modułu zrealizowano 8 spotkań partnerskich. Gospodarze / gospodynie spotkań projektowych (lokalne UTW) wybierali / wybierały, a następnie prezentowali / prezentowały wybrane przez siebie zajęcia, w których uczestniczyli / uczestniczyły słuchacze / słuchacz-

* W krajach skandynawskich, edukacja dostępna jest dla wszystkich, bez względu na wiek i pochodzenie, a idea lifelong learning widoczna jest w praktyce. Osoby dorosłe często decydują się na roczną lub dwuletnią przerwę w pracy i ponownie lub po raz pierwszy podejmują edukację formalną. Warto dodać, że tamtejsze grupy studentów są zróżnicowane wiekowo bardziej niż w Polsce. 
ki z lokalnego UTW, seniorzy / seniorki z diady (partnerski UTW), członkowie / członkinie Zespołu ds. Suprwizji, kierownicy / kierowniczki UTW i koordynatorka modułu. W trakcie realizacji modułu I partnerzy / partnerki projektu mieli / miały okazję wzajemnie się uczyć i czerpać inspiracje. Zrealizowane spotkania każdorazowo rozpoczynały się zajęciami animacyjno-integracyjnych, które umożliwiały wzajemne poznanie się słuchaczy / słuchaczek z lokalnych UTW. Działania podjęte w module I były wstępnym etapem procesu nawiązywania trwałych relacji między słuchaczami / słuchaczkami, kierownikami / kierowniczkami, koordynatorami / koordynatorkami i edukatorami / edukatorkami biorącymi udział w projekcie.

MODUŁ II - Działania edukacyjne - wykłady, warsztaty i konsultacje. Podstawowym zadaniem tego modułu była wymiana doświadczeń i upowszechnianie wiedzy. Edukatorzy / edukatorki z UTW w UWr mieli / / miały za zadanie dzielić się wiedzą z edukatorami / edukatorkami, liderami / liderkami i słuchaczami / słuchaczkami z mniejszych placówek edukacyjnych, a także sprzyjać efektywnej wymianie dobrych praktyk. Istotnym celem tego modułu było również wspieranie lokalnych UTW poprzez dzielenie się wątpliwościami i doświadczeniami mogącymi przyczynić się do rozbudowania, urozmaicenia i uatrakcyjnienia oferty lokalnych UTW. W module II partnerzy projektu mieli okazję skorzystać z: wykładów, warsztatów, szkoleń i konsultacji realizowanych w siedzibach lokalnych UTW. Lista proponowanych zajęć opracowana została w oparciu o ankietę potrzeb edukacyjnych. Słuchacze z partnerskich UTW wypełniali ją w module I, a jej wyniki stanowiły bazę dla stworzenia zindywidualizowanego programu / planu edukacyjnego. W rezultacie powstało ich 7 , po wstępnym opracowaniu wszystkie programy konsultowane były z partnerami projektu.

Zrealizowane w module II zindiwidualizowane plany edukacyjne pokazały nowe możliwości w edukacji seniorów, zachęciły partnerów projektu do kreatywnego uczestnictwa w życiu lokalnych społeczności. Znaczącym osiągnięciem tego modułu było nawiązanie współpracy między lokalnymi UTW i edukatorami z UTW w UWr, którzy zdecydowali się prowadzić zajęcia w wybranych placówkach także po zakończeniu projektu. Warsztaty, wykłady i konsultacje prowadzone były przez edukatorów w różnym wieku, dzięki czemu w projekcie realizowana była idea współpracy międzypokoleniowej.

MODUŁ III - upowszechnianie nauki, badań naukowych, działania międzygeneracyjne, zorientowany był na udostępnienie wiedzy i upowszechnianie nauki wśród słuchaczy UTW, ich aktywizację intelektualną i społeczną, poszerzanie wiedzy ogólnej i specjalistycznej, a także rozwój zainteresowań. W ramach tego modułu partnerzy połączeni w dia- 
dy uczestniczyli w wykładach, seminariach i warsztatach na WNHiP UWr. z następujących dziedzin: metodologia badań społecznych, psychologia kliniczna i społecznego niedostosowania, metodyka pracy opiekuńczo-wychowawczej, pedagogika ogólna; podstawy gerontologii społecznej, muzykologia, archeologia. Zaproszenie słuchaczy UTW na zajęcia akademickie w UWr. miało za zadanie przeciwdziałać społecznemu wykluczeniu seniorów / seniorek i ich izolacji, inspirować do podejmowania zróżnicowanych form aktywności, promować pozytywny obraz starości, rozwijać solidarność międzypokoleniową. Warto podkreślić, że formuła tego modułu sprzyjała międzypokoleniowej wymianie poglądów, wzajemnemu poznawaniu i inspirowaniu się - budowaniu przestrzeni dla międzygeneracyjnego dialogu. Inspiracją do wprowadzenia działań ukierunkowanych na międzypokoleniową integrację i upowszechniania wiedzy akademickiej był, jak wspomniano powyżej, skandynawski model nauczania.

Projekt „UTW” zwieńczyła konferencja popularno-naukowa, która odbyła się 24 listopada 2017 r. w gmachu głównym Uniwersytetu Wrocławskiego, pod patronatem Rektora UWr. W konferencji udział wzięli / wzięły uczestnicy / uczestniczki projektu (reprezentanci / reprezentantki 8 partnerskich UTW) i zaproszeni goście (przedstawiciele / przedstawicielki: Wrocławskiego Centrum Seniora, władz samorządowych Wrocławia i lokalnych UTW), łącznie około 200 osób, które miały okazję brać udział w dyskusji dotyczącej wizji UTW XXI wieku. Podczas konferencji partnerzy projektu mieli okazję przedstawić prezentacje multimedialne i postery, które zawierały wnioski, spostrzeżenia i uwagi dotyczące realizacji projektu z perspektywy lokalnych UTW - a zatem w kontekście ich potrzeb, oczekiwań, możliwości i ograniczeń. Należy podkreślić, że wystąpienia Partnerów, jako jedna $\mathrm{z}$ form ewaluacji projektu, stanowiły cenne źródło danych do dalszej analizy sytuacji UTW na Dolnym Śląsku.

\section{Kierunek rozwoju UTW - wnioski i refleksje z realizacji projektu}

Obserwowane na przestrzeni ostatnich lat, nasilające się zainteresowanie procesem starzenia się, zaowocowało powstaniem wielu publikacji o tematyce gerontologicznej. Dokonana analiza literatury naukowej wykazała, że tematyka aktywizacji osób starszych cieszy się coraz większym zainteresowaniem naukowców. Niewiele jest jednak opracowań i analiz dotyczących aktualnej sytuacji UTW na Dolnym Śląsku. 
Udzielenie odpowiedzi na postawione na początku artykułu pytania o to, jaka jest przyszłość uniwersytetów trzeciego wieku w Polsce oraz czy w drugiej dekadzie XXI wieku obserwujemy ich zmierzch, sprowokowało nas do namysłu nad kierunkiem, w jakim zmierzają współczesne uniwersytety trzeciego wieku. Przedstawione poniżej wnioski są jednym z wielu głosów w dyskusji nad ideą UTW w Polsce, mogą jednak stanowić źródło refleksji i inspiracji dla badaczy zainteresowanych problematyką celów, zadań i misji UTW.

„Moda na starość opanowała zachodnie społeczeństwa; starość robi dziś furorę" (Bois 1996, s. 11) - to stwierdzenie Jeana Pierre’a Boisa sprzed kilkudziesięciu lat wydaje się wciąż aktualne. Warto jednak zastanowić się, czy wzmożone zainteresowanie osobami starszymi wiąże się jednocześnie z intensyfikacją działań zmierzających do zaspokojenia potrzeb i oczekiwań dynamicznie zmieniającej się subpopulacji seniorów / seniorek. Fenomen starzenia się, choć budzi coraz większe zainteresowanie wśród naukowców / naukowczyń, badaczy / badaczek, edukatorów / edukatorek, polityków / / polityczek, twórców / twórczyń reklam, producentów / producentek dóbr i usług jest procesem trudnym do uchwycenia i jednoznacznego zdefiniowania, dotyczy on bowiem złożonego indywiduum ludzkiego, tym samym wymyka się uogólnieniom. Sposoby postrzegania i przedstawiania starości, jej rozumienia, definiowania i obrazowania są kulturowo i historycznie zmienne (Zakowicz 2013). Podobnie jest $z$ ideą funkcjonowania uniwersytetów trzeciego wieku, które naszym zdaniem, powinny: nadążać za dokonującymi się zmianami społeczno-kulturowymi, uwzględniać zmienność w stylach życia w starości, dostrzegać nowe potrzeby i problemy seniorów / seniorek, także tych z małych społeczności lokalnych.

Proces szeroko rozumianej aktywizacji osób starszych jest jednym z ciekawszych zagadnień gerontologicznych, a co za tym idzie coraz częściej podejmowanym przez badaczy / badaczki. Powyższą tezę zdaje się potwierdzać także stały wzrost liczby UTW w Polsce. Powstają one w dużych ośrodkach akademickich (Gdynia, Lublin, Katowice), małych miastach (Brzeg, Wiślica, Wschowa) oraz wsiach, takich jak: Ropa (wieś w woj. małopolskim, w pow. gorlickim, w gminie Ropa, http://utwropa.pl/) czy Bądków (wieś w województwie mazowieckim, w powiecie grójeckim, w gminie Goszczyn).

W świetle naszych obserwacji historia UTW w pewnym sensie zatoczyła koło. Jesteśmy bowiem - przynajmniej w pewnym sensie - w podobnej sytuacji społeczno-edukacyjnej, jak Francja w momencie powstawania 
pierwszego UTW w Tuluzie*. Podobnie jak Francja w latach 70. XX wieku, Polska mierzy się obecnie z problemami wynikającymi ze zmniejszenia się liczby studentów / studentek, przy jednoczesnym wzroście liczby wyspecjalizowanych, młodych naukowców / naukowczyń. Coraz częściej także pojawiają się pytania o to, w jakim kierunku zmierza szkolnictwo wyższe, a wraz z nim uniwersytety trzeciego wieku. Czy nadal realizuje humboldtowskie ideały, czy raczej spełnia postulaty pracodawców?

Wnioski z realizacji projektu "UTW” oraz tempo powstawania nowych UTW skłania nas do stwierdzenia, że jesteśmy świadkami renesansu idei uniwersytetów trzeciego wieku, który przejawia się ciągłym wzrostem popularności tego rodzaju placówek oraz poszukiwaniem nowych kierunków rozwoju. Po wstępnej analizie założonych i zrealizowanych w projekcie „UTW” celów, sformułowałyśmy możliwe kierunki rozwoju współczesnych UTW**, odnosząc się w głównej mierze do opinii seniorów / seniorek biorących udział w projekcie.

Angażowanie słuchaczy / słuchaczek UTW w procesy decyzyjne. Realizacja projektu „UTW” upewniła nas w przekonaniu, że współpraca oparta na partnerstwie, wsłuchiwaniu się w potrzeby i oczekiwania seniorów / seniorek, budowaniu poczucia wspólnotowości między lokalnymi UTW pozwala kreować przestrzeń sprzyjającą wzajemnemu uczeniu sie, inspirowaniu i motywowaniu do działania. Niemniej istotne jest także stwarzanie okazji do współdziałania z kierownictwem i zarządem UTW, podejmowanie inicjatyw sprzyjających angażowaniu się seniorów / seniorek, budowaniu poczucia odpowiedzialności za placówkę i realizowane w niej inicjatywy. Zachęcanie słuchaczy / słuchaczek do współtworzenia programów zajęć, planów, strategii oraz aplikowania o finansowanie projektów, daje im poczu-

* Czynników, które przyczyniły się do powstania pierwszego UTW we Francji, jak wskazuje Olga Czerniawska (2007), było kilka. Jednym z nich była rewolta młodzieży w 1968 roku, która wybuchła we Francji, a następnie ogarnęła całą Europę. Studenci / studentki domagali / domagały się reformy przestarzałego - ich zdaniem - systemu nauczania. Do powstania pierwszego UTW przyczynił się także wzrost poziomu wykształcenia społeczeństwa. Przejawiał się on zwiększeniem się liczby kadry pracującej na uczelniach wyższych, a w konsekwencji możliwością kształcenia większej liczby studentów / studentek. Tak zaczęły powstawać kolejne UTW w innych ośrodkach akademickich, a wraz z nimi upowszechniała się idea ustawicznego kształcenia.

** Zaproponowane wnioski zostały sforumowane na podstawie: opinii seniorów / seniorek wypowiadanych w trakcie spotkań z partnerami projektu w module I i II; wniosków z przeprowadzonych ankiet (moduł I), dyskusji prowadzonych w trakcie spotkań podsumowujących (moduł I i II); konkluzji przedstawionych na posterach omawianych w trakcie konferencji podsumowującej projekt oraz sprawozdań partnerów projektu. 
cie sprawstwa. Takie inicjatywy, jak zauważyłyśmy w trakcie realizacji projektu „UTW”, sprzyjają budowaniu poczucia wspólnotowości, mogą zmienić postawę z biernego słuchacza / słuchaczki - uczestnika / uczestniczki zajęć na aktywnego i kreatywnego twórcę / twórczynię oferty edukacyjnej i rekreacyjnej UTW*.

Upowszechnianie nauki - otwieranie się uczelni wyższych na seniorów / seniorki. Realizacja modułu III uświadomiła nam, jak ważne jest włączanie słuchaczy / słuchaczek UTW do środowiska studenckiego. Spotkanie seniorów / seniorek z UTW ze studentami / studentkami UWr. miało wymiar międzypokoleniowej integracji: „byliśmy na równych prawach” - mówili / / mówiły seniorzy / seniorki. W trakcie wspólnych zajęć odbywały się ciekawe dyskusje stwarzające okazję do wymiany poglądów. Wszyscy / wszystkie słuchacze / słuchaczki UTW byli / były zadowoleni / zadowolone, że mieli / / miały okazję uczestniczyć w ciekawych wykładach i pogłębić swoją wiedzę. Wspólne zajęcia były także wyzwaniem dla wykładowców / wykładowczyń, którzy / które deklarowali / deklarowały, że starsi / starsze studenci / studentki dali / dały się poznać jako osoby pytające i dociekliwe. Uczestnictwo seniorów / seniorek w zajęciach akademickich wraz ze studentami / studentkami UWr, było swoistą innowacją, która jak się okazało wzbudziła wśród seniorów / seniorek najwięcej emocji i zainteresowania. Można zatem wnioskować, że seniorzy / seniorki mają silną potrzebę dalszego kształcenia się, uczestniczenia w wykładach na poziomie akademickim, a także przebywania w grupach wiekowo zróżnicowanych, co sprzyja dialogowi międzypokoleniowemu.

Przeciwdziałanie stereotypom - tworzenie miejsc spotkań międzypokoleniowych. Za szczególną wartość projektu „UTW” (moduł III) należy uznać między innymi promocję pozytywnego wizerunku starości wśród wykładowców / wykładowczyń i studentów / studentek. Niemniej istotne było przełamywanie stereotypów i wzajemnych uprzedzeń, potwierdzeniem czego jest opinia jednej z uczestniczek modułu III, która zauważyła, że „zarówno młodzi, jak i seniorzy są siebie ciekawi”. W trakcie realizacji projektu słuchacze / słuchaczki UTW dowiedzieli / dowiedzały się także, że mają prawo uczestniczyć w wykładach uniwersyteckich jako „wolni słuchacze / wolne słuchaczki”, co jak się okazało było dla nich ważnym odkryciem.

* Jednym z dowodów potwierdzających potrzebę angażowania się słuchaczy / słuchaczek w działania organizacyjne i decyzyjne w lokalnym UTW, jest wypowiedź przewodniczącej Zespołu ds. Superwizji, która w trakcie konferencji podsumowującej projekt „UTW” wyraziła wolę zaangażowania się całego zespołu w proces pisania wniosku projektowego w przypadku ubiegania się o ponowne dofinansowanie projektu w kolejnej edycji programu pod nazwą „Wsparcie Uniwersytetów Trzeciego Wieku”. 
Promowanie idei wolontariatu seniorów / seniorek i dla seniorów / seniorek. Jak wynika z naszych obserwacji, wolontariat osób starszych cieszy się we Wrocławiu coraz większym zainteresowaniem. Za przykład może posłużyć wzrost liczby wolontariuszy angażujących się w działania realizowane między innymi przez Wrocławskie Centrum Seniora, takie jak: „Wrocławskie Dni Seniora”, projekt „Miasto Pokoleń”, „Dni Gerontologii”, „Targi Senioralne”. Ilustracją nieszablonowej aktywności wolontariackiej, jest także powołany w trakcie realizacji projektu Zespół ds. Superwizji, w skład którego wchodzili / wchodziły słuchacze / słuchaczki z UTW w UWr.

Zaangażowanie i kreatywność superwizorów / superwizorek, obserwowane na każdym etapie projektu dowiodło, że seniorzy / seniorki mogą z jednej strony dzielić się swoją wiedzą i doświadczeniami - jako eksperci / / ekspertki, mentorzy / mentorki, z drugiej natomiast stale się uczyć, zdobywać nowe kompetencje - jako refleksyjni / refleksyje obserwatorzy / obserwatorki rzeczywistości. Jak wyjaśnia jedna z członkiń Zesposłu ds. Superwizji, w trakcie projektu „mogliśmy «uczyć», a innym razem «uczyliśmy się» zdobywając nową wiedzę i nowe doświadczenia. (...) zarówno indywidualnie, jak i grupowo byliśmy superwizorami i zarazem superwizowanymi”. Potwierdza to fakt, że bez względu na wiek można odkrywać i doskonalić swoje umiejętności, być aktywnym, rozwijać w sobie potrzebę dzielenia się wiedzą, doświadczeniami, umiejętnościami - być wolontariuszem. Wolontariat, jak twierdzą seniorzy / seniorki, pozwala utrzymać stały kontakt z ludźmi, nie tylko rówieśnikami, ale także dziećmi i młodzieżą, (np. słuchacze / słuchaczki z UTW w UWr. udzielają się jako wolontariusze / wolontariuszki w szkołach, świetlicach, szpitalach i hospicjach). Działania wolontarystyczne dają seniorom / / seniorkom poczucie wartości i ważności społecznej. Pomagają w przełamywaniu stygmatyzującego stereotypu bezwartościowego „innego - starego” (Malec 2013), co potwierdzają także wspomniane działania seniorów / seniorek - wolontariuszy / wolontariuszek zaangażowanych w projekt „UTW”.

Budowanie platformy wymiany wiedzy i dobrych praktyk między lokalnymi UTW. Analiza sprawozdań Partnerskich UTW, które otrzymałyśmy po zakończeniu projektu pozwala wnioskować, że niewielkie, lokalne uniwersytety trzeciego wieku na Dolnym Śląsku poszukują równowagi między akademickością i ludycznością, starają się na nowo zdefiniować swoją tożsamość w kontekście przemian społeczno-kulturowych, lokalnych potrzeb, problemów, możliwości i oczekiwań seniorów / seniorek. Jednak aby móc powyższe cele realizować potrzebują wsparcia merytorycznego, kadrowego i finansowego. Dlatego coraz częściej podejmują inicjatywy ukierunkowane na zrzeszanie się, budowanie platform współpracy. Pozwala to wnio- 
skować, że stwarzanie okazji do wymiany doświadczeń i kadry dydaktycznej (m.in. poprzez realizację projektów), umożliwianie korzystania z konsultacji, pobudzanie do krytycznej refleksji nad funkcjonowaniem UTW, może prowadzić do rozwoju i redefinicji idei UTW.

\section{Współ/poszukiwanie alternatywnych źródeł finansowania.} Partnerzy / partnerki projektu z lokalnych UTW wielokrotnie podkreślali: „W projekcie UTW niezmiernie ważne było wsparcie finansowe oraz organizacyjne władz lokalnych, samorządowych i państwowych". Pozwalało ono bowiem na skoncentrowanie sił na realizacji projektu, na jego stronie merytorycznej, zwalniając jednocześnie z angażowania sił Zarządu w pozyskiwania środków finansowych. Warto dodać, że kierownicy UTW, szczególnie z małych miejscowości często nie wiedzą jak lub / i gdzie takie środki pozyskiwać. Dlatego też uważamy, że aplikowanie o dofinansowanie w partnerstwie z innymi, doświadczonymi UTW, a w rezultacie udział w projektach krajowych i międzynarodowych, nawiązywanie partnerstw, pozyskiwanie sponsorów, przyjmowanie darowizn jest szansą dla rozwoju szczególnie małych, lokalnych UTW.

Reasumując, projekt „UTW”, który zrealizowany został przy dużym zaangażowaniu kadry zarządzającej, kierowników / kierowniczek lokalnych UTW, Zespołu ds. Superwizji, słuchaczy / słuchaczek partnerskich placówek oraz społeczności lokalnej, pozwolił dostrzec kilka charakterystycznych tendencji, które mogą być dowodem powolnych zmian, dokonujących się we współczesnych uniwersytetach trzeciego wieku. Jedną z nich jest z pewnością wzrost zaangażowania seniorów w realizacje inicjatyw kreowanych w lokalnych UTW. Przykładem czego jest liczba certyfikatów, które rozdane zostały w trzech modułach projektu „UTW”, łącznie bowiem wręczono ich 900 (certyfikaty potwierdzające udział w wykładach, warsztatach, konsultacjach oraz działaniach animacyjnych). Warto wspomnieć, że udział w projekcie pozwolił na zbudowanie sieci współpracy, dzięki której wzbogacono ofertę dydaktyczną lokalnych UTW. Udało się wypracować dobrą praktykę wolontariatu senioralnego, a także zachęcić seniorów / seniorki i studentów / studentki do wspólnego uczestnictwa w wykładach akademickich na Wydziale Nauk Historycznych i Pedagogicznych Uniwersytetu Wrocławskiego.

W kontekście powyższych rozważań zasadnym wydaje się twierdzenie, że uniwersytety trzeciego wieku w Polsce realizują współcześnie wiele ważnych zadań, są swoistymi centrami kulturalno-edukacyjno-animacyjnymi dla osób starszych. Pozwalają seniorom / seniorkom zaspokajać potrzebę samorozwoju, umożliwiają kontakty z rówieśnikami, stwarzają warunki do kontynuowania edukacji i podejmowania inicjatyw międzypokolenio- 
wych oraz rozwoju idei wolontariatu. Warto także dodać, że UTW integrując środowiska osób starszych, zarówno na poziomie lokalnym, jak i ogólnopolskim przyczynia się do upowszechniania idei uczenia się przez całe życie, który jak podkreśla Jacques Delors „jawi się jako klucz do bram XXI wieku. Wykracza poza tradycyjny podział na edukację wstępną i edukacje ustawiczną. Jest odpowiedzią na wyzwania szybko zmieniającego się świata" (1998, s.17).

\section{Bibliografia}

Bois J. P. (1996), Historia starości od Montaigne'a do pierwszych emerytur, Volumen, Warszawa.

Czerniawska O. (2007), Szkice z andragogiki i gerontologii, Wyd. Wyższej Szkoły Humanistyczno-Ekonomicznej, Łódź.

Czerniawska O. (2009), Uniwersytet trzeciego wieku, 30 lata działania. Przemiany, dylematy i oczekiwania w epoce ponowoczesnej, „Chowanna”, t. 2.

Delors J. (1998), Edukacja - jest w niej ukryty skarb, raport dla UNESCO Międzynarodowej Komisji ds. Edukacji dla XXI wieku, Warszawa, UNESCO.

Malec M. (2011), Elderly people in small local communities of Lower Silesia - spaces of marginalization?, [w:] Fragoso W.A., Kurantowicz E., Lucio-Villegas E. (red.), Between global and local: adult learning and development, Frankfurt am Main, Peter Lang, s. 205-215.

Malec M., (2011a), Poszukiwanie recepty na starość - wyzwaniem dla edukacji dorostych: refleksje nad uczeniem się starości przez całe życie. [w:] Malec M. (red.), Edukacyjne, kulturowe i społeczne konteksty starości, Wrocław: Oficyna Wydawnicza ATUT, s. 11-28.

Malec M. (2013), Wolontariat jako przestrzeń uczenia się seniorów, [w:] Olejarz M. (red.), Dyskursy Młodych Andragogów, t. 14, s. 105-119.

Malec Rawiński M. (2013), Znaczenie krytycznej gerontologii edukacyjnej dla badań i praktyki, „Rocznik Andragogiczny”. s. 173-184.

Uniwersytet Trzeciego Wieku w UWr. (http://utw.uni.wroc.pl/utw/historia), dostęp z dnia: 02.01.2018 r.

Zakowicz I. (2013), Starość (nie) medialna, [w:] Tomczyk Ł., Wąsiński A., Seniorzy $w$ świecie nowych technologii. Implikacje dla praktyki edukacyjnej oraz rozwoju społeczeństwa informacyjnego, „Biblioteka Gerontologii Społecznej”, 2(1-2), s. 60 .

Ziębińska B. (2010), Uniwersytety trzeciego wieku jako instytucje przeciwdziałajace marginalizacji osób starszych, Wydawnictwo Naukowe „Śląsk”, Katowice.

Zych A. A. (2010), Leksykon gerontologii, Impuls, Kraków. 